\title{
Novel Quinolone Substituted Imidazol-5(4H)-ones as Anti-inflammatory, Anticancer Agents: Synthesis, Biological Screening and Molecular Docking Studies
}

\author{
Santosh Kumar', Jignesh C Aghara', Anirudh Manoj', Angel T Alex², Jesil Mathew A², Alex Joesph",* \\ 1Department of Pharmaceutical Chemistry, Manipal College of Pharmaceutical Sciences, Manipal, Karnataka, INDIA. \\ 2Department of Pharmaceutical Biotechnology, Manipal College of Pharmaceutical Sciences, Manipal, Karnataka, INDIA.
}

\begin{abstract}
Background: Quinolones and imidazolones are important heterocyclic moieties which have been reported to possess potent anti-inflammatory and anticancer properties. The activity of these compounds were related to inhibition of nuclear factor-kappaB (NF$\kappa B)$ which is one of the important targets studied for designing of anti-inflammatory and antitumor drugs. Further, hybrid pharmacophore approach is used in the present study for designing potent molecules. Objectives: Aim of the study is to synthesis a series of quinolone substituted imidazolones and evaluation of their anti-inflammatory and anticancer activity. Methods: Quinolone substituted imidazolones were synthesized by aminolysis of 7-amino-4-methyl-quinoline- $2(1 \mathrm{H})$-one with substituted oxazolones afforded quinolone substituted imidazolones. Structures of synthesized compounds were characterized by spectral techniques and were evaluated for anti-inflammatory activity by carrageenan-induced rat paw oedema test. Differences between control and treatment groups were tested using one way analysis of variance followed by Tukey's test. Anticancer activity was assessed by evaluating the cytotoxicity of compounds on BT-549 and HeLa, human cancer cell lines by MTT assay. Results: Compounds 3-fluorobenzylidene substituted imidazolonyl quinolone (F3) and 4-phenoxybenzylidene substituted imidazolonyl quinolone (F12) were the most cytotoxic compounds against BT-549 and HeLa cell lines. While 2-chlorobenzylidene substituted imidazolonyl quinolone $\left(F_{4}\right)$ and 4-chlorobenzylidene substituted imidazolonyl quinolone (F5) exhibited the highest anti-inflammatory activity. Most of the test compounds exhibited statistically significant inhibition of paw oedema volume when compared to that of control. Conclusion: Molecular docking studies revealed that combination of two pharmacophores was crucial for binding of quinolone substituted imidazol- $5(4 \mathrm{H})$-ones on NF- $\kappa B$ with good correlation between docking score and biological activity.
\end{abstract}

Key words: Anti-inflammatory, Anticancer, Docking, Quinolone, Imidazolone, NF- $\mathrm{B}$.

\section{INTRODUCTION}

In spite of rapid progress has been attained in cancer cell biology still anticancer therapy has become a major challenge because of high incidence of side effects and acquired drug resistance. Nevertheless most cancer treatments, involve chemotherapy, radiotherapy and surgery, with chemotherapy remains the most significant pharmacological approach for anticancer therapy. Owing to limitations of existing chemotherapeutic agents like side effects and acquired resistance discovery of new chemotherapeutic agents with therapeutic profile is a need of the hour. Research over the years has established a strong link between inflammation and cancer. ${ }^{1,2}$ Disease states like cancer and inflammation is strongly associated with activation of transcription factors belonging to the nuclear kappa B (NF-кB) family. Accordingly, molecules' targeting $\mathrm{NF}-\kappa \mathrm{B}$ dependent biological functions are considered of great interest
Submission Date: 01-03-2020; Revision Date: 27-04-2020; Accepted Date: 17-06-2020

DOI: 10.5530/ijper.54.3.129 Correspondence: Dr. Alex Joseph

Associate Professor, Manipal College of Pharmaceutical Sciences, Manipal Academy of Higher Education,

Manipal-576104, Karnataka, INDIA.

Phone: $+91-9448548060$ E-mail: alex.joseph@manipal.edu

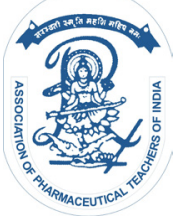

www.ijper.org 
and therefore are attractive therapeutic target for cancer and inflammation. ${ }^{3,4}$ Even though there is considerable progress in almost all the aspects of cancer research, the current therapeutic options have many disadvantages, including low efficacy and high degree of toxicity. Many cancer chemotherapeutic agents are themselves carcinogenic. ${ }^{5}$ Therefore, there is a need to rationally design novel, targeted anti-cancer therapeutics, which are selective, less toxic and ultimately more effective than existing treatments.

Imidazol-5(4H)-ones is a versatile fused heterocyclic scaffold of biological and chemical interest since long. Imidazolones have been reported for their wide range of biological activities such as anticonvulsant, sedative and hypnotic, potent CNS depressant, antihistamine, anti-filarial, bactericidal, fungicidal, anti-inflammatory, MAO inhibitory, anti-parkinsonian, antihypertensive, anthelmintic and anticancer. ${ }^{6-14}$ Moreover some authors have reported 5-imidazolones as NF- $\mathrm{\kappa B}$ inhibitors. ${ }^{15}$ The extensive therapeutic importance of imidazolones prompted us to use imidazolone as one of the pharmacophores for designing our hybrid pharmacophores targeting NF- $\kappa \mathrm{B}$.

Quinolin-2(1H)-one is biologically important heterocyclic skeleton which is present in many alkaloids and organic compounds. Quinolin-2(1H)-one are isosteric with coumarins and isomeric to quinolin$4(1 \mathrm{H})$-ones. Various quinoline-2 $(1 \mathrm{H})$-ones derivatives were found to be associated with various biological activities such as antitumor, ${ }^{16,17,18}$ antibacterial and anti-inflammatory activities ${ }^{19}$ and many substituted quinolin-2-one derivatives have recently created great interest in chemotherapy as antitumor drugs. ${ }^{16,20}$ Ruiz et al. reported cytotoxic mechanism of quinolone derivatives as alkylating agents. ${ }^{21}$ The combination of two pharmacophores on the same molecule popularly called as hybrid pharmacophore approach is a wellknown approach for the designing of more active and effective drugs with more predictable pharmacokinetic and pharmacodynamics properties. As imidazolones and quinolones moieties are experimentally proven anticancer and anti-inflammatory pharmacophores, we thought of combining these pharmacophore and additional substitutions on this scaffolds would may further enhance their activity as anticancer and antiinflammatory agents. Hence we thought of synthesizing a series of novel quinolone substituted imidazolones and screen them for their anti-inflammatory and anticancer activity.

\section{MATERIALS AND METHODS}

\section{Chemistry}

All chemicals and solvents used were of analytical or reagent grades and were used without further purification. All the chemicals were purchased from Aldrich, Sigma-aldrich, Spectrochem, Himedia and SD Fine chemicals limited, India. The purity of all compounds was established by single spot on the pre-coated silica gel plates (TLC silica gel $\mathrm{F}_{254}$, Merck, Germany). The TLC solvent systems used were chloroform: methanol (8:2), chloroform: acetone (3:7), hexane: ethyl acetate (7:3). Iodine vapour was used as developing reagent. Infrared spectra were recorded on a Shimadzu FTIR-8310 (Shimadzu, Japan) using potassium bromide discs. ${ }^{1} \mathrm{H}$ NMR spectra were recorded on a Bruker $400 \mathrm{MHz}$ spectrophotometer (Bruker, USA) in. Chemical shifts are reported in parts per million ( $\delta$ ) units relative to an internal standard of tetramethylsilane. Coupling constants are given in $\mathrm{Hz}$ and the relative peaks areas were in agreement with all assignments. Mass spectra were recorded on a Waters Q-TOF Premier spectrometer (Waters, Milford, MA, USA). Elemental analyses were performed on Leco CHNS-932 (Leco, St. Joseph, MI, USA). Melting points were determined on a capillary melting point apparatus (Shital Scientific Industries, India) and are uncorrected.

\section{Synthesis of 7-amino-4-methyl-quinoline-2(1H)- one (C)}

$10.8 \mathrm{~g}(0.1 \mathrm{~mol})$ of $\mathrm{m}$-phenylenediamine (1) and 12.64 $\mathrm{ml}(0.1 \mathrm{~mol})$ of ethylacetoacetate (2) were taken in a $250 \mathrm{ml}$ round bottom flask. The reaction mixture was refluxed for $48 \mathrm{~h}$. At the end of reaction period, $200 \mathrm{ml}$ of water was added to the flask and the contents were heated to the boiling temperature of water. The mixture was then filtered; the filtrate was chilled in refrigerator till the precipitation appeared. The precipitate was collected, dried in air, recrystallized from methanol and was characterized. (M. P. $270-272^{\circ} \mathrm{C}$, TLC Solvent system-Acetone: Chloroform- 7: 3). ${ }^{20}$

\section{Synthesis of 4-arylidene-2-pheny oxazole-5-ones $\left(E_{1}-E_{12}\right)$}

A mixture of benzaldehyde or substituted aryl aldehydes $(0.25 \mathrm{M})$, benzoyl glycine $(0.25 \mathrm{M})$, acetic anhydride $(0.75 \mathrm{M})$ and sodium acetate $(0.25 \mathrm{M})$ were taken in a $500 \mathrm{ml}$ conical flask and heat on an electric hot plate with constant shaking. As soon as the mixture has liquefied completely, transfer the flask to a water bath and heat for $2 \mathrm{~h}$. Added $100 \mathrm{ml}$ of ethanol slowly to 
the contents of the flask and allow the mixture to stand overnight. Filter the crystalline product with suction, wash with two $25 \mathrm{ml}$ portions of ice cold alcohol and wash with two $25 \mathrm{ml}$ portions of boiling water, dry at $100^{\circ} \mathrm{C}$ and recrystallized from benzene. (TLC Solvent system-Hexane: Ethyl acetate- 7: 3).

\section{Synthesis of Quinolone substituted imidazol- $5(4 \mathrm{H})$-ones $\left(\mathrm{F}_{1}-\mathrm{F}_{12}\right)$}

General method: To a solution of 4-arylidene-2-pheny oxazole-5-ones $(0.005 \mathrm{M})$ in $15 \mathrm{~mL}$ of dry pyridine, added 7-amino-4-methyl-quinoline-2(1H)-one $(0.005 \mathrm{M})$ in portions with constant stirring for $10 \mathrm{~min}$. The reaction mixture was refluxed for $9 \mathrm{~h}$. The hot solution was added to a beaker containing $100 \mathrm{~g}$ of crushed ice and $5 \mathrm{ml}$ of con. $\mathrm{HCl}$. The solid separated was filtered, dried and recrystallized from methanol to give pure product. (TLC Solvent system- Chloroform: Methanol - 8: 2). ${ }^{19}$ 7-(4-bensylidene-5oxo-2-phenyl-4,5-dibydro-1H-imidazol-1-yl)-4-methylquinolin2(1H)-one $\left(F_{1}\right)$ : Crystallized from methanol to give white crystals, yield $71 \%$; mp 276-278 $\left({ }^{\circ} \mathrm{C}\right)$; IR (KBR, $\gamma$, $\left.\mathrm{cm}^{-1}\right)$ : 3419.31 (N-H str.), $2922.16\left(\mathrm{C}-\mathrm{H}\right.$ str. Of $\left.\mathrm{CH}_{3}\right)$, $1654.38(\mathrm{C}=\mathrm{O}$ str. of quinolone ring), $1612.85(\mathrm{C}=\mathrm{N}$ str.), 1571.86 (C=C str.),1398.21 (C-N str.); ${ }^{1} \mathrm{H}$ NMR (DMSO- $\left.d_{\sigma}, \delta \mathrm{ppm}, 400 \mathrm{MHz}\right): 11.507$ (s, 1H, -NH-), 7.195 (s, 1H, Ar-CH=), 7.08-8.05 (m, 13H, Ar-H), 6.25 (s, $1 \mathrm{H},=\mathrm{CH}$ - of quinolone ring), $2.32\left(\mathrm{~s}, 3 \mathrm{H},-\mathrm{CH}_{3}\right)$; TOF MS $\mathrm{ES}^{+}(\mathrm{m} / \mathrm{z}): 406[\mathrm{M}+1]^{+}, 423\left[\mathrm{M}+\mathrm{H}_{2} \mathrm{O}\right]^{+}$; Analysis for $\mathrm{C}_{26} \mathrm{H}_{19} \mathrm{~N}_{3} \mathrm{O}_{2}$ : Calcd \% C, 77.02; $\mathrm{H}, 4.72 ; \mathrm{N}$, 10.36. Found \%: C, 76.98; H, 4.69; N, 10.29 .

7-(4-(4-fluorobenzylidene)-5-oxo-2-phenyl-4,5-dibydro-1 Himidazol-1-yl)-4-metbylquinolin-2(1H)-one $\left(\mathrm{F}_{2}\right)$ : Crystallized from methanol to give white crystals, yield $67 \%$; mp 280 $282\left({ }^{\circ} \mathrm{C}\right) ; \mathrm{IR}\left(\mathrm{KBR}, \gamma, \mathrm{cm}^{-1}\right): 3417.86$ (N-H str.), 2922.16 (C-H str. of $\left.\mathrm{CH}_{3}\right), 1649.5$ ( $\mathrm{C}=\mathrm{O}$ str. of quinolone ring), 1612.49 (C=N str.), 1575.84 (C=C str.),1398.39 (C-N str.); ${ }^{1} \mathrm{H}$ NMR (DMSO- $d_{6}, \delta$ ppm, $400 \mathrm{MHz}$ ): 11.502 (s, 1H, -NH-), 7.197 (s, 1H, Ar-CH=), 7.06-8.05 (m, 12H, Ar- $\mathrm{H}), 6.29$ (s, $1 \mathrm{H},=\mathrm{CH}$ - of quinolone ring), 2.43 (s, $3 \mathrm{H}$, $\left.-\mathrm{CH}_{3}\right)$; TOF MS ES $(m / 2): 423[\mathrm{M}]^{+}, 441\left[\mathrm{M}+\mathrm{H}_{2} \mathrm{O}\right]^{+}$; Analysis for $\mathrm{C}_{26} \mathrm{H}_{18} \mathrm{FN}_{3} \mathrm{O}_{2}$ : Calcd \% C, 73.75; H, 4.28; N, 9.92. Found \%: C, 73.71; H, 4.26; N, 9.88.

7-(4-(3-fluorobenzylidene)-5-oxo-2-phenyl-4,5-dibydro-1 Himidazol-1-yl)-4-methylquinolin-2(1H)-one $\left(\mathrm{F}_{3}\right)$ : Crystallized from methanol to give white crystals, yield 69\%; mp 275 $278\left({ }^{\circ} \mathrm{C}\right)$; IR $\left(\mathrm{KBR}, \gamma, \mathrm{cm}^{-1}\right): 3416.15$ (N-H str.), 2920.73 (C-H str. of $\left.\mathrm{CH}_{3}\right), 1648.2$ (C=O str. of quinolone ring), 1611.51 (C=N str.), 1573.39 (C=C str.),1396.25 (C-N str.); ${ }^{1} \mathrm{H}$ NMR (DMSO-d, $, \delta \mathrm{ppm}, 400 \mathrm{MHz}$ ): 11.510 (s, 1H, -NH-), 7.151 (s, 1H, Ar-CH=), 7.05-8.05 (m, 12H, Ar- $\mathrm{H}$ ), 6.27 (s, 1H, =CH- of quinolone ring), 2.41 (s, 3H, $\left.-\mathrm{CH}_{3}\right)$; $\mathrm{TOF} \mathrm{MS} \mathrm{ES}^{+}(\mathrm{m} / \mathrm{s}): 423[\mathrm{M}]^{+}, 441\left[\mathrm{M}+\mathrm{H}_{2} \mathrm{O}\right]^{+}$;
Analysis for $\mathrm{C}_{26} \mathrm{H}_{18} \mathrm{FN}_{3} \mathrm{O}_{2}$ : Calcd \% C, 73.75; H, 4.28; N, 9.92. Found \%: C, 73.71; H, 4.26; N, 9.88.

7-(4-(2-chlorobenaylidene)-5-oxo-2-phenyl-4,5-dibydro-1 Himidazol-1-yl)-4-methylquinolin-2(1H)-one ( $\left.\mathrm{F}_{4}\right)$ : Crystallized from methanol to give white crystals, yield 75\%; mp 286$287\left({ }^{\circ} \mathrm{C}\right)$; IR (KBR, $\left.\gamma, \mathrm{cm}^{-1}\right): 3421.32$ (N-H str.), 2927.13 (C-H str. of $\left.\mathrm{CH}_{3}\right), 1649.5$ ( $\mathrm{C}=\mathrm{O}$ str. of quinolone ring), 1614.29 (C=N str.), 1571.29 (C=C str.),1385.19 (C-N str.); ${ }^{1} \mathrm{H}$ NMR (DMSO- $d_{6}$, $8 \mathrm{ppm}, 400 \mathrm{MHz}$ ): 11.541 (s, $1 \mathrm{H},-\mathrm{NH}-), 7.21$ (s, $1 \mathrm{H}, \mathrm{Ar}-\mathrm{CH}=), 7.04-8.07(\mathrm{~m}, 12 \mathrm{H}$, Ar-H), 6.31 (s, 1H, =CH- of quinolone ring), 2.39 (s, $\left.3 \mathrm{H},-\mathrm{CH}_{3}\right) ;$ TOF MS ES ${ }^{+}(\mathrm{m} / \mathrm{s}): 439[\mathrm{M}]^{+}, 441[\mathrm{M}+2]^{+}$, $457\left[\mathrm{M}+\mathrm{H}_{2} \mathrm{O}\right]^{+}$; Analysis for $\mathrm{C}_{26} \mathrm{H}_{18} \mathrm{ClN}_{3} \mathrm{O}_{2}$ : Calcd \% C, 70.99; H, 4.12; N, 9.55. Found \%: C, 70.85; H, 4.09; N, 9.51.

7-(4-(4-chlorobenzylidene)-5-oxo-2-phenyl-4,5-dibydro-1 Himidazol-1-yl)-4-methylquinolin-2(1H)-one $\left(\mathrm{F}_{5}\right)$ : Crystallized from methanol to give white crystals, yield 70\%; mp 295$297\left({ }^{\circ} \mathrm{C}\right)$; IR (KBR, $\left.\gamma, \mathrm{cm}^{-1}\right): 3419.71$ (N-H str.), 2931.58 (C-H str. of $\left.\mathrm{CH}_{3}\right), 1651.9$ (C=O str. of quinolone ring), 1616.62 (C=N str.), 1576.75 (C=C str.),1387.41 (C-N str.); ${ }^{1} \mathrm{H}$ NMR (DMSO- $d_{6}$, $\delta$ ppm, $400 \mathrm{MHz}$ ): 11.571 (s, 1H, -NH-), 7.31 (s, 1H, Ar-CH=), 7.07-8.09 (m, 12H, Ar-H), 6.39 (s, 1H, =CH- of quinolone ring), 2.44 (s, $\left.3 \mathrm{H},-\mathrm{CH}_{3}\right)$; $\mathrm{TOF} \mathrm{MS} \mathrm{ES}^{+}(\mathrm{m} / \mathrm{z}): 439[\mathrm{M}]^{+}, 441[\mathrm{M}+2]^{+}$, $457\left[\mathrm{M}+\mathrm{H}_{2} \mathrm{O}\right]^{+}$; Analysis for $\mathrm{C}_{26} \mathrm{H}_{18} \mathrm{ClN}_{3} \mathrm{O}_{2}$ : Calcd $\% \mathrm{C}$, 70.99; H, 4.12; N, 9.55. Found \%: C, 70.87; H, 4.07; N, 9.49 .

7-(4-(4-bromobenzylidene)-5-oxo-2-phenyl-4,5-dibydro-1Himidazol-1-yl)-4-methylquinolin-2(1H)-one (Fo): Crystallized from methanol to give white crystals, yield $78 \%$; mp 291 $293\left({ }^{\circ} \mathrm{C}\right)$; IR (KBR, $\left.\gamma, \mathrm{cm}^{-1}\right): 3411.21$ (N-H str.), 2971.32 (C-H str. of $\left.\mathrm{CH}_{3}\right), 1671.2$ (C=O str. of quinolone ring), 1619.39 (C=N str.), 1584.75 (C=C str.),1391.41 (C-N str.); ${ }^{1} \mathrm{H}$ NMR (DMSO- $d$, 8 ppm, $400 \mathrm{MHz}$ ): 11.631 (s, 1H, -NH-), 7.41 (s, 1H, Ar- $\mathrm{CH}=), 7.06-8.07$ (m, 12H, Ar-H), 6.35 (s, 1H, =CH- of quinolone ring), 2.41 (s, $\left.3 \mathrm{H},-\mathrm{CH}_{3}\right)$; TOF MS ES $(\mathrm{m} / \mathrm{z}): 484[\mathrm{M}]^{+}, 486[\mathrm{M}+2]^{+}$; Analysis for $\mathrm{C}_{26} \mathrm{H}_{18} \mathrm{BrN}_{3} \mathrm{O}_{2}$ : Calcd \% C, 64.47; H, 3.75; N, 8.68. Found \%: C, 63.91; H, 3.45; N, 8.39.

7-(4-(2-bromoben aylidene)-5-oxo-2-phenyl-4,5-dibydro-1Himidazol-1-yl)-4-methylquinolin-2(1H)-one $\left(F_{7}\right)$ :Crystallized from methanol to give off white crystals, yield $73 \%$; mp 285-287 $\left({ }^{\circ} \mathrm{C}\right)$; IR $\left(\mathrm{KBR}, \gamma, \mathrm{cm}^{-1}\right): 3419.77(\mathrm{~N}-\mathrm{H}$ str.), 2975.75 (C-H str. of $\left.\mathrm{CH}_{3}\right), 1677.5$ (C=O str. of quinolone ring), 1625.24 ( $\mathrm{C}=\mathrm{N}$ str.), 1591.54 ( $\mathrm{C}=\mathrm{C}$ str.), 1399.64 (C-N str.); ${ }^{1} \mathrm{H}$ NMR (DMSO- $d_{6}$, $8 \mathrm{ppm}, 400$ $\mathrm{MHz})$ : 11.625 (s, 1H, -NH-), 7.45 (s, 1H, Ar-CH=), 7.07$8.07(\mathrm{~m}, 12 \mathrm{H}, \mathrm{Ar}-\mathrm{H}), 6.38(\mathrm{~s}, 1 \mathrm{H},=\mathrm{CH}-$ of quinolone ring), 2.43 (s, 3H, $-\mathrm{CH}_{3}$ ); TOF MS ES ${ }^{+}(\mathrm{m} / \mathrm{s}): 484[\mathrm{M}]^{+}$, $486[\mathrm{M}+2]^{+}$; Analysis for $\mathrm{C}_{26} \mathrm{H}_{18} \mathrm{BrN}_{3} \mathrm{O}_{2}$ : Calcd \% C, 
64.47; H, 3.75; N, 8.68. Found \%: C, 64.53; H, 3.85; N, 8.79 .

7-(4-(4-methoxybenzylidene)-5-oxo-2-phenyl-4,5-dibydro-1Himidazol-1-yl)-4-methylquinolin-2(1H)-one $\left(\mathrm{F}_{8}\right)$ : Crystallized from methanol to give off white crystals, yield $65 \%$; mp 255-257 $\left({ }^{\circ} \mathrm{C}\right)$; IR $\left(\mathrm{KBR}, \gamma, \mathrm{cm}^{-1}\right): 3411.16(\mathrm{~N}-\mathrm{H}$ str.), 2967.42 (C-H str. of $\left.\mathrm{CH}_{3}\right), 1671.8$ (C=O str. of quinolone ring), $1617.82(\mathrm{C}=\mathrm{N}$ str.), $1585.92(\mathrm{C}=\mathrm{C}$ str.), 1385.33 (C-N str.); ${ }^{1} \mathrm{H}$ NMR (DMSO- $d_{6}$, $8 \mathrm{ppm}, 400$ $\mathrm{MHz}$ ): 11.575 (s, 1H, -NH-), 7.31 (s, 1H, Ar-CH=), 7.01$8.01(\mathrm{~m}, 12 \mathrm{H}, \mathrm{Ar}-\mathrm{H}), 6.25(\mathrm{~s}, 1 \mathrm{H},=\mathrm{CH}-$ of quinolone ring), $3.90\left(\mathrm{~s}, 3 \mathrm{H},-\mathrm{OCH}_{3}\right), 2.36\left(\mathrm{~s}, 3 \mathrm{H},-\mathrm{CH}_{3}\right)$; TOF $\mathrm{MS} \mathrm{ES}^{+}(\mathrm{m} / \mathrm{z}): 435[\mathrm{M}]^{+}, 458[\mathrm{M}+\mathrm{Na}]^{+}$; Analysis for $\mathrm{C}_{27} \mathrm{H}_{21} \mathrm{~N}_{3} \mathrm{O}_{3}$ : Calcd C, 74.47; H, 4.86; N, 9.65. Found \%: C, 74.53; H, 4.85; N, 9.79 .

7-(4-(2-methoxybensylidene)-5-oxo-2-phenyl-4,5-dibydro-1Himidazol-1-yl)-4-metbylquinolin-2(1H)-one $\left(\mathrm{F}_{g}\right)$ : Crystallized from methanol to give off white crystals, yield $69 \%$; mp 259-263 $\left({ }^{\circ} \mathrm{C}\right)$; IR $\left(\mathrm{KBR}, \gamma, \mathrm{cm}^{-1}\right): 3415.45(\mathrm{~N}-\mathrm{H}$ str.), 2969.69 (C-H str. of $\left.\mathrm{CH}_{3}\right), 1680.5$ (C=O str. of quinolone ring), $1621.91(\mathrm{C}=\mathrm{N}$ str.), $1592.91 \quad(\mathrm{C}=\mathrm{C}$ str.), 1388.68 (C-N str.); ${ }^{1} \mathrm{H}$ NMR (DMSO- $d_{6}$, $8 \mathrm{ppm}, 400$ $\mathrm{MHz}$ ): 11.481 (s, 1H, -NH-), 7.39 (s, 1H, $\mathrm{Ar}-\mathrm{CH}=)$, 7.04$8.04(\mathrm{~m}, 12 \mathrm{H}, \mathrm{Ar}-\mathrm{H}), 6.35$ (s, $1 \mathrm{H},=\mathrm{CH}$ - of quinolone ring), $3.89\left(\mathrm{~s}, 3 \mathrm{H},-\mathrm{OCH}_{3}\right), 2.51\left(\mathrm{~s}, 3 \mathrm{H},-\mathrm{CH}_{3}\right)$; TOF MS $\mathrm{ES}^{+}(\mathrm{m} / \mathrm{z}): 435[\mathrm{M}]^{+}, 458[\mathrm{M}+\mathrm{Na}]^{+}$; Analysis for $\mathrm{C}_{27} \mathrm{H}_{21} \mathrm{~N}_{3} \mathrm{O}_{3}$ : Calcd C, 74.47; H, 4.86; N, 9.65. Found \%: C, 74.11; H, 4.61; N, 9.74.

7-(4-(3,4-dimethoxybensylidene)-5-oxo-2-phenyl-4,5-dibydro1H-imidazol-1-yl)-4-methylquinolin-2(1H)-one $\quad\left(\mathrm{F}_{10}\right)$ : Crystallized from methanol to give off white crystals, yield $72 \%$; mp 255-257 $\left({ }^{\circ} \mathrm{C}\right)$; IR (KBR, $\left.\gamma, \mathrm{cm}^{-1}\right): 3417.31$ (N-H str.), 2955.51 (C-H str. of $\left.\mathrm{CH}_{3}\right), 1685.7$ (C=O str. of quinolone ring), $1621.81(\mathrm{C}=\mathrm{N}$ str.), $1586.41(\mathrm{C}=\mathrm{C}$ str.),1379.15 (C-N str.); ${ }^{1} \mathrm{H}$ NMR (DMSO- $d_{\sigma}$, $\delta$ ppm, 400 $\mathrm{MHz}$ ): 11.311 (s, 1H, -NH-), 7.29 (s, 1H, Ar- $\mathrm{CH}=)$, 7.02$8.03(\mathrm{~m}, 11 \mathrm{H}, \mathrm{Ar}-\mathrm{H}), 6.31$ (s, 1H, =CH- of quinolone ring), $3.81\left(\mathrm{~s}, 3 \mathrm{H},-\mathrm{OCH}_{3}\right), 3.83\left(\mathrm{~s}, 3 \mathrm{H},-\mathrm{OCH}_{3}\right), 2.45$ (s, $\left.3 \mathrm{H},-\mathrm{CH}_{3}\right)$; TOF MS ES ${ }^{+}(\mathrm{m} / \mathrm{z}): 465[\mathrm{M}]^{+}$Analysis for $\mathrm{C}_{28} \mathrm{H}_{23} \mathrm{~N}_{3} \mathrm{O}_{4}$ : Calcd C, 72.25; H, 4.98; N, 9.03. Found \%: C, 72.17; H, 4.81; N, 9.04.

7-(4-(4-ethoxybenzylidene)-5-oxo-2-phenyl-4,5-dibydro1H-imidazol-1-yl)-4-methylquinolin-2(1H)-one (F11): Crystallized from methanol to give off white crystals, yield $61 \%$; mp $251-253\left({ }^{\circ} \mathrm{C}\right)$; IR $\left(\mathrm{KBR}, \gamma, \mathrm{cm}^{-1}\right): 3419.39$ (N-H str.), 2972.56 (C-H str. of $\left.\mathrm{CH}_{3}\right), 1685.3$ (C=O str. of quinolone ring), 1615.37 ( $\mathrm{C}=\mathrm{N}$ str.), 1565.46 (C=C str.), 1365.31 (C-N str.); ${ }^{1} \mathrm{H}$ NMR (DMSO- $d_{\sigma}$, $\delta \mathrm{ppm}, 400$ $\mathrm{MHz}$ ): 11.571 (s, 1H, -NH-), 7.33 (s, 1H, Ar-CH=), 7.01$8.01(\mathrm{~m}, 12 \mathrm{H}, \mathrm{Ar}-\mathrm{H}), 6.24(\mathrm{~s}, 1 \mathrm{H},=\mathrm{CH}-$ of quinolone ring), $3.95\left(\mathrm{~m}, 2 \mathrm{H},-\mathrm{OCH}_{2} \mathrm{CH}_{3}\right), 2.36\left(\mathrm{~s}, 3 \mathrm{H},-\mathrm{CH}_{3}\right), 1.55$ $\left(\mathrm{t}, 3 \mathrm{H},-\mathrm{OCH}_{2} \mathrm{CH}_{3}\right) ; \mathrm{TOF} \mathrm{MS} \mathrm{ES}^{+}(\mathrm{m} / \mathrm{z}): 449[\mathrm{M}]^{+}, 472$
$[\mathrm{M}+\mathrm{Na}]^{+}$; Analysis for $\mathrm{C}_{28} \mathrm{H}_{23} \mathrm{~N}_{3} \mathrm{O}_{3}$ : Calcd C, 74.82; H, $5.16 ; \mathrm{N}, 9.35$. Found $\%$ : C, 74.61; H, 4.92; N, 9.27.

4-methyl-7-(5-oxo-4-(4-phenoxybenzylidene)-2-phenyl4,5-dibydro-1H-imidazol-1-yl)quinolin-2(1H)-one $\left(\mathrm{F}_{12}\right)$ : Crystallized from methanol to give off white crystals, yield $67 \%$; mp 261-262 $\left({ }^{\circ} \mathrm{C}\right)$; IR $\left(\mathrm{KBR}, \gamma, \mathrm{cm}^{-1}\right): 3421.42$ (N-H str.), 2975.89 (C-H str. of $\left.\mathrm{CH}_{3}\right), 1687.9$ (C=O str. of quinolone ring), 1619.91 ( $\mathrm{C}=\mathrm{N}$ str.), $1562.72(\mathrm{C}=\mathrm{C}$ str.), 1371.91 (C-N str.); ${ }^{1} \mathrm{H}$ NMR (DMSO-d, , $8 \mathrm{ppm}, 400$ $\mathrm{MHz}): 11.541$ (s, 1H, -NH-), 7.39 (s, 1H, Ar-CH=), 7.08$8.07(\mathrm{~m}, 17 \mathrm{H}, \mathrm{Ar}-\mathrm{H}), 6.24(\mathrm{~s}, 1 \mathrm{H},=\mathrm{CH}-$ of quinolone ring), 2.39 (s, $3 \mathrm{H},-\mathrm{CH}_{3}$ ); TOF MS ES $(\mathrm{m} / \mathrm{s}): 497[\mathrm{M}]^{+}$; Analysis for $\mathrm{C}_{32} \mathrm{H}_{23} \mathrm{~N}_{3} \mathrm{O}_{3}$ : Calcd $\mathrm{C}, 77.25 ; \mathrm{H}, 4.66 ; \mathrm{N}$, 8.45. Found \%: C, 76.99; H, 4.52; N, 8.17.

\section{Biological Evaluation}

Animals: Animal care and handling were done as per guidelines of Committee for the Purpose of Control and Supervision of Experiments on Animals, (CPCSEA), Govt. of India. The experimental protocol was approved by Institutional Animal Ethics Committee (IAEC), Kasturba Medical College, Manipal-5761004, India (Registration No. IAEC/KMC/04/2013-2014). Albino rats of Charles foster species were used for antiinflammatory studies. The animals were acclimatized to the experimental room having temperature $27 \pm 3^{\circ} \mathrm{C}$, controlled humidity conditions and 14:10 h light and dark cycle. The four animals were housed in each polypropylene cage containing paddy husk as bedding. The mice were fed on autoclaved standard mice food pellets (Hindustan Lever Ltd., New Delhi) and water ad libitum.

\section{Toxicological study (OECD 425 Guidelines)}

Acute toxicity study was done and safe dose was calculated as per OECD test guideline $425 .{ }^{22}$

\section{Anti-inflammatory activity}

Carrageenin-induced paw oedema test was performed on albino rats of charles foster species. Groups of six rats of both sex (body weight 150-200 g), pregnant females excluded, were given a $100 \mathrm{mg} / \mathrm{kg}$ oral dose of a test compounds. $1 \mathrm{~h}$ later, $0.2 \mathrm{~mL}$ of $1 \%$ carrageenan suspension in $0.9 \% \mathrm{NaCl}$ solution was injected subcutaneously, into the subplantar tissue of the right hind paw of each mouse and the paw volume was measured with a plethysmometer (UGO Basile 7140, model-7141, Biological research apparatus, Italy) and then measured again $3 \mathrm{~h}$ later. Indomethacin $(10 \mathrm{mg} / \mathrm{kg})$ was used as reference drug. The mean increase of paw volume was compared with that of control group (six rats received only carrageenan, but not test compounds) and percent inhibition values were calculated by the 
formula: $\%$ anti-inflammatory activity $=1-\mathrm{D}_{\mathrm{t}} / \mathrm{D}_{\mathrm{c}} \times$ 100. Where $\mathrm{D}_{t}$ represents the percentage difference in increased paw volume after the administration of test drugs to the rats and $\mathrm{D}_{\mathrm{c}}$ represents the percentage difference of increased volume in the control group. ${ }^{23}$

\section{Anticancer study}

Cell lines: Human breast carcinoma cell line (BT549), Human cervical adenocarcinoma cell line (HeLa) were procured from National Centre for Cell Science, Pune, India. The BT-549 and HeLa were cultured in the RPMI-1640 medium with 2mM L-glutamine adjusted to contain $1.5 \mathrm{~g} / \mathrm{L}$ sodium bicarbonate and supplemented with $10 \%$ FBS, $10000 \mathrm{U} / \mathrm{ml}$ penicillin and $10 \mathrm{mg} / \mathrm{ml}$ streptomycin. Both cell lines were incubated at $37^{\circ} \mathrm{C}$, in $5 \% \mathrm{CO}_{2}$ humidified atmosphere.

\section{In vitro cytotoxic study (MTT assay)}

In vitro cytotoxicity of synthesized compounds was evaluated by MTT assay. ${ }^{24}$ In brief, exponentially growing BT-549 and HeLa cells were plated in 96-well plates $\left(10^{4}\right.$ cells/well, in $100 \mu \mathrm{l}$ of media) and incubated for $24 \mathrm{~h}$ to obtain $60-80 \%$ confluency. The test compounds were solubilized in $50 \mu \mathrm{l}$ DMSO and were further diluted with media so as to get DMSO concentration less than $0.25 \%$. The cells were then exposed to different concentration of test compounds (500, 250, 125, 62.5, $31.25,15.62,7.81 \mu \mathrm{g} / \mathrm{ml})$ in the volume of $100 \mu \mathrm{l} /$ well. The control wells received only cells containing media and $0.25 \%$ DMSO. Cisplatin was used as positive control. Media was removed after $48 \mathrm{~h}$ and $100 \mu \mathrm{l}$ MT'T reagent $(1 \mathrm{mg} / \mathrm{ml})$ was added to cell cultures and then kept for incubation at $37^{\circ} \mathrm{C}$ for $4 \mathrm{~h}$. The viable cells developed formazan complex; was solubilized by addition of $100 \mu \mathrm{l}$ DMSO. The plates were placed on micro-vibrator for $5 \mathrm{~min}$. The absorbance was recorded on BIOTEK EL X800- MS microtiter plate reader at $540 \mathrm{~nm}$ and percentage cytotoxicity was calculated as (control-test/control) $\times 100$.

\section{Statistical analysis}

The statistical analyses were performed by one way analysis of variance, followed by Tukey's post hoc test using GraphPad Prism 5.02. The results are expressed as the mean \pm S.D. Statistical significance was set at $p<0.05$ level.

\section{Molecular docking into DNA binding site of NF-kB}

Library of forty two quinolone susbstituted imidazol$5(4 \mathrm{H})$-ones derivatives was prepared by using chemdraw ultra 11.0. These derivatives were differing in their substitution at arylidene moiety of quinolone substituted imidazol-5(4H)-ones. The 3D crystal structures of the NF- $\kappa \mathrm{B}$ were obtained from Protein Data Bank (PDB codes: $1 \mathrm{NFK}$ and 1LE9). ${ }^{25,26}$ The 3D structures of NF- $\kappa \mathrm{B}, \mathrm{p} 50-\mathrm{p} 50$ homodimer (from 1NFK), p50 monomer chain A (p50a from 1NFK), p50 monomer chain B (p50b from 1NFK; p50b from 1LE9) were used for virtual screening. The co-crystallized DNA and water molecules were removed and AutoDock 4.2 was used for molecular docking studies. Docking parameters were set to default values on the basis of Lamarckian genetic algorithm principle. ${ }^{27}$ The twelve compounds with highest estimated free energy of binding were selected for wet lab synthesis. Synthesized compounds were biologically evaluated for anti-inflammatory and anticancer study and attempt was made to establish structure-activity relations of compounds to explore new lead compounds.

\section{RESULTS AND DISCUSSION \\ Chemistry}

Synthesis of quinolone substituted imidazol-5(4H)ones involves 3 steps. In first step, 7-amino-4methyl-quinoline-2(1H)-one (3) was synthesized by cyclocondensation of m-phenylenediamine (A) and ethylacetoacetate (B) (Scheme). Step-2 involves synthesis of 4-arylidene-2-pheny oxazole-5-ones (5a$5 \mathrm{~g})$ derivatives by Erlenmeyer azlactone synthesis of substituted oxazolones by reaction of various aryl aldehydes with hippuric acid in the prescence of acetic anhydride (Scheme). While in step-3 aminolysis 4-arylidene-2-pheny oxazole-5-ones $\left(\mathrm{E}_{1}-\mathrm{E}_{12}\right)$ derivatives with 7-amino-4-methyl-quinoline-2 $(1 H)$-one $(\mathrm{C})$ by refluxing in dry pyridine yielded the title compounds quinolone substituted imidazol-5 $(4 \mathrm{H})$-ones $\left(\mathrm{F}_{1}-\mathrm{F}_{12}\right)$. The reactions proceed by initial nucleophilic attack of amino group of 7 -amino-4-methyl-quinoline- $2(1 H)$-one on the carbonyl carbon of 4-arylidene-2-pheny oxazole5 -ones followed by ring opening by the breakage of $\mathrm{C}-\mathrm{O}$ bond followed by intramolecular cyclization with elimination of water. Progresses of the reactions were monitored by TLC using chloroform: methanol (8:2) as mobile phase. The synthesized compounds were purified by column chromatography using silica gel 100200 mesh and later by recrystallization in methanol to afford white/ yellowish-white products. The yields of synthesized compounds ranged from $61-78 \%$.

Structures of synthesized title compounds were confirmed by IR, NMR and Mass techniques. The FT-IR $(\mathrm{KBr})$ spectra displayed characteristic absorption bands corresponding to $\mathrm{N}-\mathrm{H}, \mathrm{C}=\mathrm{O}, \mathrm{C}=\mathrm{C}, \mathrm{C}=\mathrm{N}$ and $\mathrm{C}-\mathrm{N}$, stretching vibrations. IR spectra of all quinolone substituted thiazolidin-4-ones showed N-H stretching 
in the range of $3421.42-3411.16 \mathrm{~cm}^{-1}$. The vibrational frequency at $1648.2-1687.9 \mathrm{~cm}^{-1}$ confirmed the presence of carbonyl group in synthesized compounds. Other characteristic peaks $\mathrm{C}=\mathrm{C}, \mathrm{C}=\mathrm{N}$ and $\mathrm{C}-\mathrm{N}$ appeared at 1562.72-1592.91, 1615.37-1625.24 and1365.31-1399.64 $\mathrm{cm}^{-1}$ respectively. NMR spectra of all the compounds showed NH proton in the range of 11.502-11.625 $\mathrm{ppm}$ as a broad signal. The methine proton $(=\mathrm{CH}-)$ of quinolone appeared as a singlet between 6.24-6.39 ppm. TOF MS ES ${ }^{+}$spectra showed characteristic $\mathrm{M}^{+} /$ $[\mathrm{M}+1]^{+}$peaks corresponding to molecular weight of synthesized compounds.

\section{Biological evaluation \\ Anti-inflammatory activity}

The anti-inflammatory activity of newly synthesized twelve compounds was evaluated by carrageenaninduced paw oedema model in rats using indomethacin as a reference drug. Results are expressed as mean \pm S.D. (Table 1). Differences between control and treatment groups were tested using one way analysis of variance followed by tukey's test. The test compounds administered $1 \mathrm{~h}$ prior to carrageenan injection at a dose of $100 \mathrm{mg} / \mathrm{kg}$ body wt. caused significant inhibition of paw oedema volume. Compounds A3 and A4, possessing chloro substitution on ortho and para position of benzylidene group of imidazol$5(4 \mathrm{H})$-one moiety respectively, confers maximum antiinflammatory activity with a percentage paw oedema inhibition of 31.34 and 29.61 respectively. While compounds A1, A2, A3, A6 and A7 exhibited moderate activity with a percentage paw edema inhibition ranging from 17.39-26.71. In general compounds with electron withdrawing groups such as chlorine/fluorine/bromine substitutions on benzylidene ring of imidazolone moiety showed better anti-inflammatory activity. Pattern of percentage oedema inhibition among test compounds bearing halogen substituted benzylidene ring of imidazolone moiety was seen as: chloro $>$ fluoro $>$ bromo substitution.

\section{In vitro cytotoxic studies (MTT assay)}

In the present work, newly synthesized twelve compounds were screened for their in vitro growth inhibitory activities against two human cultured cell lines namely, human breast carcinoma cell line (BT-549) and Human cervical adenocarcinoma cell line (HeLa) at concentrations ranging from 7.81-500 $\mu \mathrm{g} / \mathrm{ml}$ by MTT assay method. Results are shown as concentration $(\mu \mathrm{g} /$ $\mathrm{ml} \pm$ S.D) which exhibited $50 \%$ cell death $\left(\mathrm{IC}_{50}\right)$ after $48 \mathrm{~h}$ of incubation (Table 2). Among the synthesized compounds compound A3 with 3-fluorobenzylidene substitution on imidazol-5(4H)-one moiety confers maximum cytotoxicity with an $\mathrm{IC}_{50}$ value of $19.57 \pm 1.94$ and $21.19 \pm 1.99 \mu \mathrm{g} / \mathrm{ml}$ respectively on BT-549 and HeLa cells. The second highest cytotoxic compound was A12 bearing 4-phenoxybenzylidene substituted imidazol-5(4H)-one with an $\mathrm{IC}_{50}$ value of $25.77 \pm 2.13$ and $29.72 \pm 2.78 \mu \mathrm{g} / \mathrm{ml}$ respectively on BT-549 and HeLa cells. Other moderately active compounds were A1 and A2 with unsubstituted benzylidene moiety and 3-fluorobenzylidene moiety respectively on imidazol$5(4 \mathrm{H})$-one showed $\mathrm{IC}_{50}$ below $50 \mu \mathrm{g} / \mathrm{ml}$. Among the other compounds most of the compounds exhibited $\mathrm{IC}_{50}$ below $100 \mu \mathrm{g} / \mathrm{ml}$. In general compounds with fluorine, chlorine or phenoxy substitutions on benzylidene ring of imidazolone moiety showed better growth inhibitory activity against HeLa and BT-549 cells.

\section{Molecular docking study}

The 3D structures of NF-kB-DNA complex was taken from Protein Data Bank (PDB code: 1NFK) and co-crystallized DNA was removed. The p50 dimer and p50 monomers (chains A and B) were used for the virtual screening and structures were prepared by using Chem Draw Ultra 11.0. All the water molecules were removed and hydrogens were added to protein. Library of forty two molecules was docked into the binding site of receptor using Autodock 4.2. ${ }^{28}$ Virtual screening results are expressed in terms of estimated free energy of binding (docking score) in Table 3. Estimated free energy of binding for all forty two

\begin{tabular}{|c|c|c|}
\hline \multicolumn{3}{|c|}{$\begin{array}{c}\text { Table 1: Effect of test compounds on carrageenan } \\
\text { induced paw oedema in rats }\end{array}$} \\
\hline Compound & $\begin{array}{c}\text { Dose (mg/kg } \\
\text { po) }\end{array}$ & $\begin{array}{c}\text { \%Oedema inhibition } \\
\pm \text { SD }^{\mathrm{b}}\end{array}$ \\
\hline $\mathbf{F}_{1}$ & 100 & $17.39 \pm 1.28^{\mathrm{a}}$ \\
\hline $\mathbf{F}_{\mathbf{2}}$ & 100 & $24.45 \pm 1.39^{\mathrm{a}}$ \\
\hline $\mathbf{F}_{\mathbf{3}}$ & 100 & $26.71 \pm 1.17^{\mathrm{a}}$ \\
\hline $\mathbf{F}_{\mathbf{4}}$ & 100 & $31.34 \pm 2.11^{\mathrm{a}}$ \\
\hline $\mathbf{F}_{\mathbf{5}}$ & 100 & $29.61 \pm 1.93^{\mathrm{a}}$ \\
\hline $\mathbf{F}_{\mathbf{6}}$ & 100 & $20.77 \pm 1.15^{\mathrm{a}}$ \\
\hline $\mathbf{F}_{\mathbf{7}}$ & 100 & $17.95 \pm 0.98^{\mathrm{a}}$ \\
\hline $\mathbf{F}_{\mathbf{8}}$ & 100 & $13.39 \pm 1.25$ \\
\hline $\mathbf{F}_{\mathbf{9}}$ & 100 & $11.31 \pm 0.91$ \\
\hline $\mathbf{F}_{10}$ & 100 & $13.29 \pm 1.17$ \\
\hline $\mathbf{F}_{11}$ & 100 & $9.72 \pm 0.93$ \\
\hline $\mathbf{F}_{12}$ & 100 & $11.38 \pm 0.95$ \\
\hline Indomethacin & 10 & $39.57 \pm 2.37^{\mathrm{a}}$ \\
\hline
\end{tabular}

aOne way ANOVA followed by Tukey's test, $\mathrm{a}=p<0.05$ Vs Control group ${ }^{\mathrm{b}}$ Average of six determinations 
Table 2: In vitro cytotoxicity of compounds towards BT-549 and HeLa cells.

\begin{tabular}{|c|c|c|}
\hline \multirow{2}{*}{ Compound } & \multicolumn{2}{|c|}{ IC $_{50} \mu \mathbf{g} / \mathbf{m} \mathbf{I S D}^{\mathrm{a}}$} \\
\cline { 2 - 3 } & $\mathrm{BT}-549$ & HeLa \\
\hline$F^{1}$ & $41.51 \pm 3.28$ & $54.79 \pm 2.19$ \\
\hline$F_{2}$ & $34.22 \pm 2.97$ & $42.58 \pm 2.94$ \\
\hline$F_{3}$ & $19.57 \pm 1.58$ & $21.19 \pm 1.71$ \\
\hline$F_{4}$ & $73.68 \pm 4.81$ & $78.18 \pm 3.18$ \\
\hline$F_{5}$ & $60.20 \pm 4.18$ & $59.40 \pm 3.25$ \\
\hline$F_{6}$ & $87.53 \pm 4.55$ & $95.39 \pm 3.76$ \\
\hline$F_{7}$ & $79.49 \pm 3.29$ & $75.41 \pm 2.99$ \\
\hline$F_{8}$ & $104.05 \pm 5.71$ & $111.21 \pm 4.28$ \\
\hline$F_{9}$ & $94.06 \pm 4.22$ & $99.47 \pm 3.20$ \\
\hline$F_{10}$ & $96.98 \pm 3.83$ & $87.31 \pm 3.11$ \\
\hline$F_{11}$ & $101.66 \pm 3.74$ & $107.39 \pm 3.46$ \\
\hline$F_{12}$ & $25.77 \pm 3.26$ & $29.72 \pm 1.97$ \\
\hline Cisplatin & $3.62 \pm 0.75$ & $5.51 \pm 0.71$ \\
\hline
\end{tabular}

aAverage of three determinations

molecules ranged from -11.95 to $-6.57 \mathrm{kcal} / \mathrm{mol}$. Twelve compounds with estimated free energy of binding ranging from -11.95 to $-8.57 \mathrm{kcal} / \mathrm{mol}$ were synthesized and selected for biological evaluation. The best ranked compound A3 with 3-fluorobenzylidene substitution on imidazol-5(4H)-one moiety showed estimated free energy of binding, $-11.95 \mathrm{kcal} / \mathrm{mol}$. Docked structure of A3 (compound with highest cytotoxicity) with p50 dimer (Figure 1) reveals that carbonyl $(>\mathrm{C}=\mathrm{O})$ group of quinolone moiety along with nitrogen $(=\mathrm{N}-)$ of imidazol-5(4H)-one moiety were involved in hydrogen bonding with Lys 144 and Leu 207 residues of binding site respectively. The $>\mathrm{C}=\mathrm{O}$ group of quinolone formed hydrogen bond with $-\mathrm{NH}_{2}$ group of Lys $144(\mathrm{O} \ldots \mathrm{H}-\mathrm{N}$ : $1.952 \AA$ ) , while nitrogen $(=\mathrm{N}-)$ of imidazol- $5(4 \mathrm{H})$-one moiety interacted with $-\mathrm{NH}_{2}$ group of Leu 207 (N...H$\mathrm{N}: 1.85 \AA$ Á) by hydrogen bonding. Visual inspection of docked structure of A3 with receptor shows carbonyl oxygen of quinolone ring nitrogen $(=\mathrm{N}-)$ of imidazol$5(4 \mathrm{H})$-one moiety contributed for the hydrogen bonding interaction. Thus the binding conformation of compound A3 shows that combination of two pharmacophores quinolone and imidazol-5(4H)-one might have played a crucial role in pharmacological profile of quinolone substituted imidazol-5(4H)-ones.

\section{CONCLUSION}

A library of forty two quinolone substituted imidazol$5(4 \mathrm{H})$-ones were designed based on the structure of active site of NF- $\kappa B$ protein and were subjected to virtual screening. Based on the results of virtual
Table 3: Estimated free energy of binding of synthesized compounds on the target NF-KB as dimer (p50-p50)

\begin{tabular}{|c|c|}
\hline Compound & Estimated free energy of binding ( kcal/mol) \\
\hline$F_{1}$ & -9.81 \\
\hline$F_{2}$ & -10.23 \\
\hline$F_{3}$ & -11.95 \\
\hline$F_{4}$ & -10.41 \\
\hline$F_{5}$ & -10.12 \\
\hline$F_{6}$ & -9.20 \\
\hline$F_{7}$ & -9.15 \\
\hline$F_{8}$ & -9.11 \\
\hline$F_{9}$ & -8.57 \\
\hline$F_{10}$ & -9.15 \\
\hline$F_{11}$ & -8.75 \\
\hline$F_{12}$ & -10.48 \\
\hline
\end{tabular}

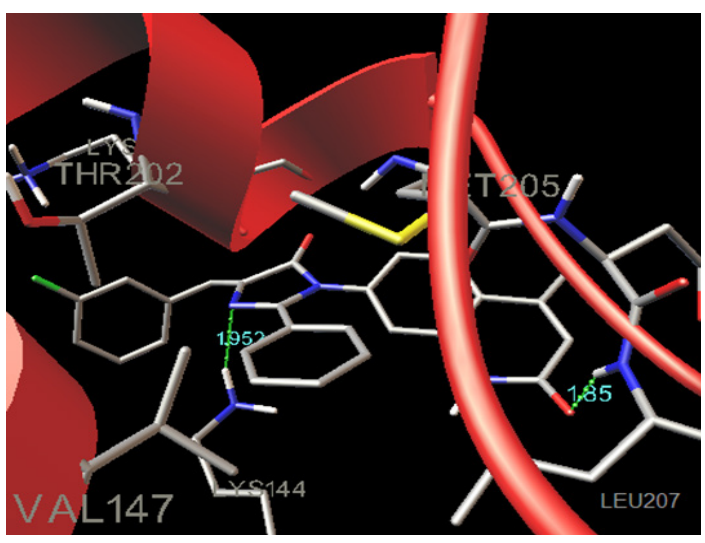

Figure 1: Stereoview of the complex formed by NF-KB homodimer and the docked compound $\mathrm{F}^{3}$. The amino acids Lys 144 and Leu 207 were involved in hydrogen bonding interaction with the compound $\mathrm{F}_{3}$.

screening top ranked twelve quinolone substituted imidazol-5(4H)-ones were identification based on their docking scores indicating their ability to bind with NF- $\kappa \mathrm{B}$ protein. Further; results of docking studies confirm our hypothesis that conjugation of two pharmacophores might improve pharmacological profile of resulted/final pharmacophore. As carbonyl oxygen of quinolone ring and nitrogen $(=\mathrm{N}-)$ of imidazol-5 $(4 \mathrm{H})$-one moiety contributed for the hydrogen bonding interaction with various amino acids of receptor which resulted into better binding of compounds with NF- $\mathrm{KB}$. Selected compounds were further synthesized in lab and biologically evaluated for anti-inflammatory and anticancer activity. Cyclocondensation of $\mathrm{m}$-phenylenediamine with 

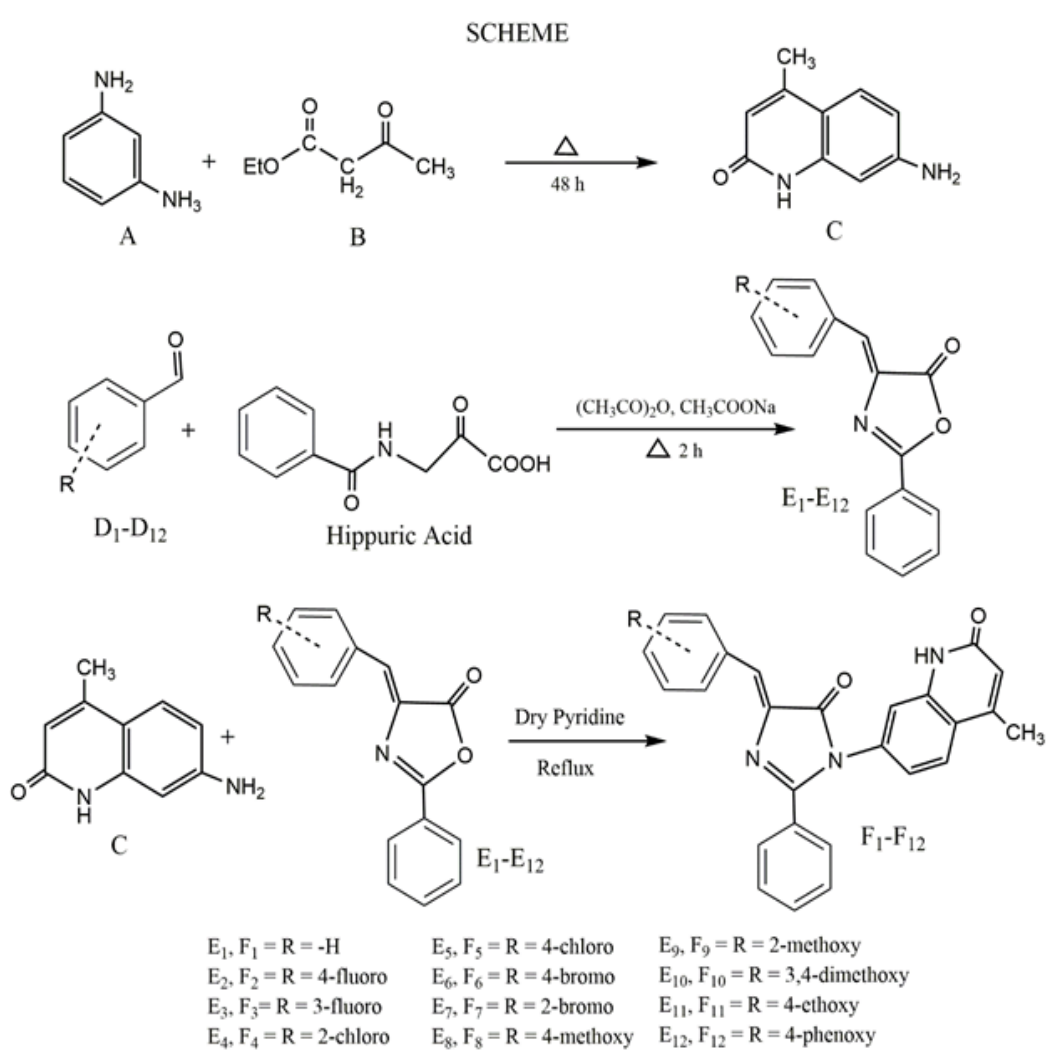

Scheme: Synthetic scheme of quinolone substituted imidazol-5(4H)-ones $\left(F_{1}-F_{12}\right)$.

ethylacetoacetate yielded 7-amino-4-methyl-quinoline$2(1 H)$-one. In Step-2 synthesis of 4-arylidene-2pheny oxazole-5-ones derivatives were carried out by Erlenmeyer azlactone synthesis of substituted oxazolones by reaction of various aryl aldehydes with hippuric acid in the prescence of acetic anhydride. While in step-3 aminolysis 4-arylidene-2-pheny oxazole-5-ones derivatives with 7-amino-4-methyl-quinoline-2(1H)-one by refluxing in dry pyridine yielded the title compounds quinolone substituted imidazol-5(4H)-ones. Synthesis of test compounds was confirmed by IR, NMR and Mass spectra. In vivo anti-inflammatory activity of test drugs in carrageenan-induced paw oedema model identified compounds A4 and A5 as potent anti-inflammatory agents. Very good agreement existed between docking score and anti-inflammatory potency of screened drugs. In vitro anticancer activity of synthesized compounds was evaluated against BT-549 and HeLa human cancer cell lines. A fair correlation was observed between docking scores and anticancer potency of synthesized compounds. Among the synthesized compounds A3 and A12 exhibited maximum cytotoxic effect against BT-549 and HeLa human cancer cell lines. Compounds A4 and A5 are distinctly potent anti-inflammatory agents as exhibited by in vivo anti-inflammatory study and similarly compound A3 and A12 exhibited potent cytotoxicity against BT-549 and HeLa human cancer cell lines, these compounds may be developed as lead molecules for anti-inflammatory and anticancer activities respectively.

\section{ACKNOWLEDGEMENT}

The authors thank the Indian Institute of Science, Bangalore for NMR spectra and SAIF labs of Central Drug Research Institute, Lucknow and Punjab University for Mass Analysis. We are also grateful to Principal, Manipal College of Pharmaceutical Sciences, and Head, Dept. of Pharmaceutical Chemistry, Manipal College of Pharmaceutical Sciences, MAHE for providing necessary research facilities.

\section{CONFLICT OF INTEREST}

The authors declare no conflict of interest.

\section{ABBREVIATIONS}

FTIR: Fourier transform infrared spectroscopy; NMR: Nuclear magnetic resonance spectroscopy; Q-TOF: Quadrupole time of flight mass spectrometry; TLC: Thin layer chromatography; MTT: 3-(4,5-Dimethylthiazol2-yl)-2,5-Diphenyltetrazolium bromide; OECD: 
Organization for economic co-operation and development; DMSO: Dimethyl sulphoxide.

\section{REFERENCES}

1. Coussens LM, Werb Z. Inflammation and cancer. Nature. 2002;420(6917):8607.

2. Takada Y, Bhardwaj A, Potdar P, Aggarwal BB. Nonsteroidal anti-inflammatory agents differ in their ability to suppress NF-KB activation, inhibition of expression of cyclooxygenase-2 and cyclin D1 and abrogation of tumor cell proliferation. Oncogene. 2004;23(57):9247-58.

3. Xia L, Tan S, Zhou Y, Lin J, Wang H, Oyang L, et al. Role of the NF-kBsignaling pathway in cancer. Onco Targets Ther. 2018;11:2063-73.

4. Liu T, Zhang L, Joo D, Sun SC. NF-KB signaling in inflammation. Signal Transduct Target Ther. 2017;2:17023:1-9.

5. Sirisoma N, Pervin A, Zhang H, Jiang S, Willardsen JA, Anderson MB Discovery of $\mathrm{N}$-(4-methoxyphenyl)-N,2-dimethylquinazolin-4-amine, a potent apoptosis inducer and efficacious anticancer agent with high blood brain barrier penetration. J Med Chem. 2009;52(8):2341-51.

6. Wagdy ME, Mohamed AA, Alessio N, Silvia B, Sara TR, Ghada SH, et al. Synthesis, biological evaluation and in silico studies with 4-benzylidene2-phenyl-5(4H)-imidazolone-based benzenesulfonamides as novel selective carbonic anhydrase IX inhibitors endowed with anticancer activity. Bioorg Chem. 2019;90:103102.

7. Abdelsattar MO, Tamer MA, Mohamed SA, Abdulrahman MA, Mohamed FR, Moustafa EE. Design, Synthesis and Antiproliferative Activities of Oxidative Stress Inducers Based on 2-Styryl-3,5-dihydro-4H-imidazol-4-one Scaffold. Chem Pharm Bull. 2018;66(10):967-75.

8. Luigi A, Alfonso M, Pierluigi R, Afro G, Enzo Z, Nicola DT, et al. Derivatives of imidazoles. III. Synthesis and pharmacological activities of nitrile, amides and carboxylic acid derivatives of imidazo[1,2-a] pyridine. J Med Chem. 1969;12(1):122-6.

9. Godefroi EF, Platje JTJ. DL- I-(alpha-methylbenzyl)-2-methylimidazole5-carboxylate esters: Synthesis and pharmacological properties. J Med Chem. 1972;15(3):336-7.

10. Upadhyay PS, Joshi HD, Baxi AJ, Parikh AR. Synthesis and pharmacological evaluation of some new imidazolinones as anticonvusants. Indian J Heterocyc Chem. 1991;71(1):90-4.

11. Harfenist M, Soroko EF, Mckenzie GM. 2-(Alkoxyaryl)-2-imidazoline monoamine oxidase inhibitors with antidepressant activity. J Med Chem. 1978;21(4):405-9.

12. Mukerji D, Nautiyal SR, Prasad CR. Synthesis of some new 1-(2'-methoxy4'-nitrophenyl)-2-methyl-4-substituted benzylidine-5-imidazolones as CNS depression compounds. Indian Drugs. 1981;18:125.

13. Meenakshi S, Reena K, Renu S, Dixit KS, Nath C, Barthwal JP. Synthesis, anticonvusant and enzyme inhibitory activities of some indolyl-1,3,4thiadiazoles. Indian J Chem. 1990;29(B):85.
14. Heba AE, Samar AA. Synthesis and anticancer evaluation of imidazolinone and benzoxazole derivatives. Arabian Journal of Chemistry. 2017;10;2:S372531.

15. Jetze JT. Nf-kb inhibitors and uses thereof. WIPO (PCT) WO2003101954A2. 2008;11:2003.

16. Mohamed JA, Sunil S, Rita Y, Mohamed ZH, Mohammed AB, Surender SJ, et al. Synthesis and Antiproliferative Activity of Some Quinoline and Oxadiazole Derivatives. Org Chem Int. 2016;1-9.

17. Joseph B, Darro F, Behard A, Lesur B, Collignon F, Decaestecker C, et al. 3-aryl-2-quinolone derivatives: Synthesis and characterization of in vitro and in vivo antitumor effects with emphasis on a new therapeutical target connected with cell migration. J Med Chem. 2002;45(12):2534-55.

18. Alex J, Aravinda P, Srinivasan KK, Tukaram K, Angel TA, Jessy EM, et al. Synthesis and anticancer activity of some novel 3-(1,3,4-thiadiazol-2-yl)quinazolin-4(3H)-ones. Orbital Elec J Chem. 2010;2(2):158-67.

19. Ruiz FM, Gil-Redondo R, Morreale A, Ortiz AR, Fabrega C, Bravo J. Structure-based discovery of novel non-nucleosidic DNA alkyltransferase inhibitors: Virtual screening and in vitro and in vivo activities. J Chem Inf Model. 2008;48(4):844-54.

20. Zhang Q, Chen Y, Zheng YQ, Xia P, Xia Y, Yang ZY. Synthesis and bioactivity of 4,10-dimethyl-pyridino[2,3-h]quinolin-2(1H)-one-9-carboxylic acid and its esters. Bioorg Med Chem. 2003;11(6):1031-4.

21. Abhishek K, Jennifer F, Pankaj K. Synthesis, antimicrobial and antiinflammatory activity of newly synthesized isoxazoline incorporated 2-Quinolones. Int J Pharm Sci Drug Res. 2014;6(2):124-7.

22. Acute Oral Toxicity: Up-and-Down Procedure. In: OECD Guidelines for the Testing of Chemicals, Section 4, Health Effects Test No. 425; OECD. 2008;127.

23. Kumar A, Bansal D, Bajaj K, Sharma S, Archana, Srivastava VK. Synthesis of some newer derivatives of 2-amino benzoic acid as potent anti-inflammatory and analgesic agents. Bioorg Med Chem. 2003;11(23):5281-91.

24. Mosmann T. Rapid colorimetric assay for cellular growth and survival: Application to proliferation and cytotoxicity assays. J Immunol Methods. 1983;65(1-2):55-63.

25. Piccagli L, Fabbri E, Borgatti M, Bianchi N, Bezzerri V, Mancini I, et al. Virtual screening against p50 NF-kappaB transcription factor for the identification of inhibitors of the NF-kappa B-DNA interaction and expression of NF-kappaB upregulated genes. Chem Med Chem. 2009;4(12):2024-33.

26. Piccagli L, Borgatti M, Nicolis E, Bianchi N, Mancini I, Lampronti I, et al. Virtual screening against nuclear factor $\mathrm{kB}(\mathrm{NF}-\mathrm{kB})$ of a focus library: Identification of bioactive furocoumarin derivatives inhibiting NF-KB dependent biological functions involved in cystic fibrosis. Bioorg Med Chem. 2010;18(23):8341-9.

27. Cosconati S, Forli S, Perryman AL, Harris R, Goodsell DS, Olson AJ. Virtual Screening with AutoDock: Theory and practice. Expert Opin Drug Discov. 2010;5(6):597-607.

28. Borgatti M, Chilin A, Piccagli L, Lampronti I, Bianchi N, Mancini I, et al. Development of a novel furocoumarin derivative inhibiting NF-KB dependent biological functions: Design, synthesis and biological effects. Eur J Med Chem. 2010;46(10):4870-7.

\section{SUMMARY}

- Molecular docking studies of a library of quinolone substituted quinazolin-4(3H)-ones enabled to rank compounds according to their binding affinity towards NF- $\kappa \mathrm{B}$ protein.

- Top ranked novel seven compounds with highest docking scores were synthesized and characterized by spectral techniques.

- The synthesized compounds were evaluated for anti-inflammatory activity by carrageenan-induced rat paw oedema test.

- The anticancer activity was assessed by evaluating the cytotoxic effect of synthesized compounds on BT-549 and HeLa, human cancer cell lines.

- Virtual screening studies reveal that combination of two pharmacophores was crucial for binding of quinolone substituted quinazolin-4(3H)-ones on NF-кB. 


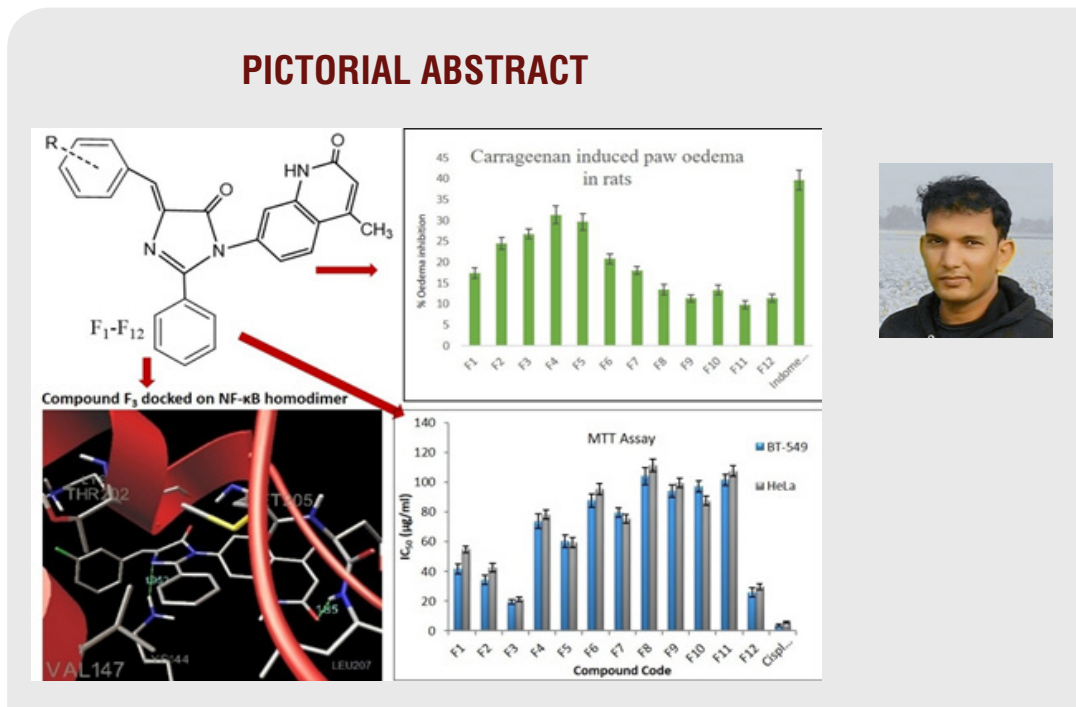

\section{About Authors}

Mr. Santosh Kumar has completed his M. Pharm in Pharmaceutical Chemistry from Department of Pharmaceutical Chemistry, Manipal College of Pharmaceutics Sciences, Manipal Academy of Higher Education, Manipal, Karnataka, India. His area of research interest in drug discovery and development. Currently, he is working for a multi-national company.

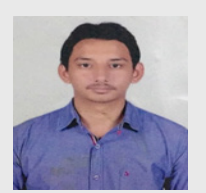

Mr. Jignesh Chhaganbhai Aghara has completed his M Pharm in Pharmaceutical Chemistry from Department of Pharmaceutical Chemistry, Manipal College of Pharmaceutics Sciences, Manipal Academy of Higher Education, Manipal, Karnataka, India. His area of research interest in synthetic organic and medicinal chemistry. Currently, he is working as a Senior Executive, Microlabs Ltd. Bangalore.

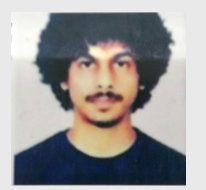

Mr. Anirudh Manoj has completed his M Pharm in Pharmaceutical Chemistry from Department of Pharmaceutical Chemistry, Manipal College of Pharmaceutics Sciences, Manipal Academy of Higher Education, Manipal, Karnataka, India. His area of research interest in synthetic organic and medicinal chemistry.

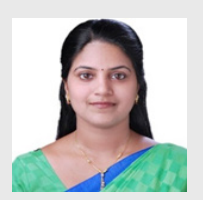

Dr. Angel Treasa Alex is presently working as an Assistant Professor (Senior Scale) at Department of Pharmaceutical Biotechnology, Manipal College of Pharmaceutical Sciences, Manipal Academy of Higher Education, Manipal, Karnataka, India. Dr. Angel is engaged in teaching and research since eight years. She has more than 20 research articles in peer reviewed journals and also contributed several book chapters. She is a life member of Association of Pharmaceutical Teachers of India (APTI) and also a reviewer and editorial board member of various peer reviewed journals. She has been awarded twice with good teacher award and also recently awarded with TMA gold medal for best research paper.

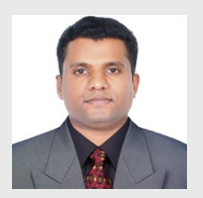

Dr. Jesil Mathew Aranjani is presently working as an Associate Professor at Department of Pharmaceutical Biotechnology, Manipal College of Pharmaceutical Sciences, Manipal Academy of Higher Education, Manipal, Karnataka, India. Dr. Jesil is engaged in teaching and research since 19 years. He has more than 34 research articles in peer reviewed journals and his area of research interest is in cancer biology and bacterial biofilms. He is a life member of Association of Pharmaceutical Teachers of India (APTI) and Indian Association of Cancer Research (IACR). He is reviewer and editorial board member of various peer reviewed journals.

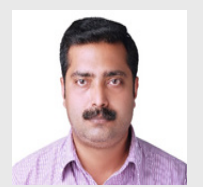

Dr. Alex Joseph is presently working as an Associate Professor at Department of Pharmaceutical Chemistry, Manipal College of Pharmaceutical Sciences, Manipal Academy of Higher Education, Manipal, Karnataka, India. Dr. Alex is engaged in teaching and research since 19 years. He has more than 50 research articles in peer reviewed journals and also contributed several book chapters. He is a life member of Association of Pharmaceutical Teachers of India (APTI) and also a reviewer and editorial board member of various peer reviewed journals. He has been awarded with good teacher award for four times and his area of research interest is in design and synthesis of novel heterocyclic compounds as anticancer, anti-inflammatory and anti-diabetic agents.

Cite this article: Kumar S, Aghara JC, Manoj A, Alex AT, Mathew JA, Joesph A. Novel Quinolone Substituted Imidazol-5(4H)-ones as Anti-inflammatory, Anticancer Agents: Synthesis, Biological Screening and Molecular Docking Studies. Indian J of Pharmaceutical Education and Research. 2020;54(3):771-80. 